\title{
Comparative genetic analysis between red-legged partridges (Alectoris rufa) and chukar partridges (A. chukar): identification of single-nucleotide polymorphisms
}

\author{
Cristina Belén GARcía, María Victoria ARRUGA* \\ Laboratory of Cytogenetics and Molecular Genetics, Faculty of Veterinary, University of Zaragoza, \\ Miguel Servet 177, 50013 Zaragoza, Spain
}

(Received 1 March 2005 - Accepted 13 February 2006)

\begin{abstract}
Populations of red-legged partridges have been decreasing due to many factors such as the deterioration of their natural habitat or increasing hunting pressure and according to laws only pure red-legged partridges can be used to repopulate wherever necessary. Little information is available about the DNA sequence of the red-legged partridge. For this reason, it was necessary to carry out a comparative analysis with other avian species that have been studied in more detail, such as the chicken. Searching of single nucleotide polymorphisms (SNP) was used to analyse various genes in these species with respect to the red-legged partridge and chukar partridge in order to characterise and differentiate between these two species. The genes analysed were the growth hormone, $37 L R P / p 40$ and $M C 1 R$ genes. Many SNP were found between the chicken and partridges but translations of exonic regions were only different for the $M C 1 R$ gene. Two interspecific SNP in partridges were found which can be used to differentiate between these two species in order to identify Alectoris chukar individuals and to avoid repopulating with them.
\end{abstract}

SNP / red-legged partridge / growth hormone gene / 37LRP/p40 gene / MC1R gene

Résumé - Analyse génétique comparative entre les perdrix rouges (Alectoris rufa) et les perdrix choukar (A. chukar) : identification des polymorphismes de nucléotides simples. La population des perdrix rouges a fortement diminué ces dernières décennies en raison de nombreux facteurs, parmi lesquels : la détérioration de l'habitat naturel et une pression croissante de chasse. Selon la loi, la repopulation doit se faire, quand cela est nécessaire, avec des perdrix rouges de race pure. Peu d'informations sont disponibles au sujet de la séquence de l'ADN des perdrix rouges. Pour cette raison, une analyse comparative avec d'autres espèces d'oiseaux, qui ont été étudiées plus en détails, comme le poulet, s'est révélée nécessaire. La recherche de polymorphismes de nucléotides simples (SNP) a été utilisée pour analyser divers gènes de l'espèce Gallus gallus et les comparer à ceux de la perdrix rouge et de la bartavelle afin de caractériser et différencier ces deux espèces. Les gènes analysés ont été le gène de l'hormone de croissance, le gène 37LRP/p40 et le

\footnotetext{
*Corresponding author: mvarruga@unizar.es
} 
gène $M C 1 R$. De nombreux SNP communs ont été mis en évidence entre l'espèce Gallus gallus et les perdrix, mais seules les traductions des exons ont été différentes pour le gène $M C 1 R$. Deux SNP spécifiques chez les perdrix ont été identifiés. Ils pourraient être utilisés pour différencier les deux espèces afin d'identifier les individus Alectoris choukar et éviter ainsi la repopulation avec cette espèce.

$\mathrm{SNP}$ / perdrix rouge / gène de l'hormone de croissance / gène 37LRP/p40 / gène $M C 1 R$

\section{INTRODUCTION}

The red-legged partridge (Alectoris rufa) is an avian species (Fig. 1) that can be found in the wild in the Iberian Peninsula, southern France and some parts of northern Italy and southern England. Their numbers have decreased in the past decades due to several factors, including the deterioration of their natural habitat and increasing hunting pressure. This species even appears in the list of species of European conservation concern because of its threat status [25]. As a result, efforts have been made to breed them in captivity to reintroduce or repopulate areas. Legally, only pure red-legged partridges can be used to repopulate and hunters prefer these animals because of their behaviour in the wild. However, many captive breeding farms use hybrid breeders that have been crossed with chukar (A. chukar) or rock partridges (A. graeca), in an attempt to increase productivity. The hybrids are often difficult to tell apart from the pure red-legged partridges and can reproduce normally in the wild, thereby contaminating the gene pool of native redlegged partridges.

Some attempts have been made to analyse the genetic makeup of $A$. rufa $[3,4,8$, $11,17,19,21]$, but more in depth studies are required, partly because of its economic value as a hunting game or meat production and its ecological importance.

Little is known about the DNA sequence of the red-legged partridge. Before this study there was only one nuclear gene sequence in the GenBank database [9] corresponding to intron $\mathrm{G}$ of the ovomucoid

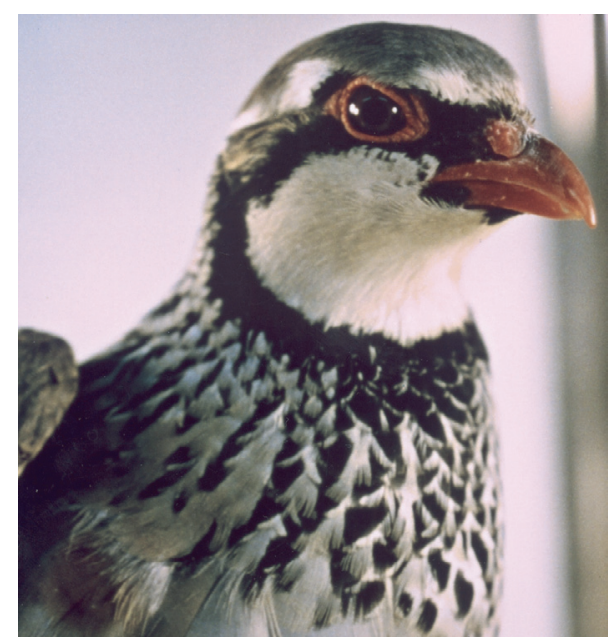

Figure 1. Red-legged partridge image.

gene [2] and the rest corresponds to mitochondrial DNA sequences.

When little information is available about the genome of a species, it can be compared with fully sequenced genes from related species, in this case the chicken Gallus gallus [18,22,23]. The growth hormone gene in chickens was compared between the red-legged partridge and the chukar partridge, since they have different growth rates (greater in A. chukar compared to A. rufa). This enabled us to obtain more information about their gene sequences as well as to identify interspecific single nucleotide polymorphisms (SNP) in an intronic region. The gene of the growth hormone in chickens has five exons and four introns [24] and it is very polymorphic in this species $[7,13,15,26]$. 
Some primers that hybridise in the two consecutive exons of $37 \mathrm{LRP} / \mathrm{p} 40$ of the $G$. gallus gene were also selected since this gene has the highest ratio of number of SNP per number of compared base pairs in an intronic region in a previous study on avian SNP [18]. The $37 L R P / p 40$ gene is composed of 7 exons and 6 introns and it codes for the metastasis-associated 37LRP7/p40 protein [5].

Finally, the $M C 1 R$ (melanocortin 1receptor) gene was selected to be studied because of the different plumage colour in different partridge species. Mutations of this gene are associated with feather colour in the chicken $[12,16]$.

The objective was to look for SNP since they are abundant in the genome and their inheritance is more stable than other fragments, such as repeated sequences [14].

\section{MATERIALS AND METHODS}

Samples from the red-legged partridge were obtained from different farms (26 samples) and wild individuals (4) in Spain. Chukar partridges were obtained from farms in Spain (6), Argentina (4), Cyprus island (2) and Greece (2) and wild individuals from Greece (6). DNA samples extracted from blood samples kept on FTA $^{\circledR}$ cards were used. Using this technique, 2 or 3 drops of blood are only required, minimising the contact and disturbance of the animals.

The sequences used in this study were sequences of the gene primers $37 L R P / p 40$ that had already been used in other species in previous studies [18] and that hybridise on exons 5 and 6 of this gene (Tab. I). The software program Primer3 [20] was used to design the primers for the growth hormone and the $M C 1 R$ gene (Tab. I).

The PCR reactions were carried out in a thermocycler MJ Research PTC $/ 100^{\mathrm{TM}}$ in a total volume of $25 \mu \mathrm{L}$ with 0.75 units of Taq polymerase, $250 \mathrm{nM}$ of each primer for the growth hormone gene and $500 \mathrm{nM}$ of each primer for the $37 L R P / p 40$ and the $M C 1 R$ genes, $100 \mu \mathrm{M}$ of each dNTP for the growth hormone gene and $200 \mu \mathrm{M}$ of each dNTP for the $37 L R P / p 40$ and the $M C 1 R$ genes, $1.5 \mathrm{mM} \mathrm{MgCl}_{2}$ and PCR buffer with $16.6 \mathrm{mM}\left(\mathrm{NH}_{4}\right)_{2} \mathrm{SO}_{4}, 67 \mathrm{mM}$ Tris- $\mathrm{HCl}$ $(\mathrm{pH}=8)$ and $0.01 \%$ Tween-20.

The PCR protocols for the gene were the following: $94{ }^{\circ} \mathrm{C}$ for $4 \min 30 \mathrm{~s}$, followed by 35 cycles at $94{ }^{\circ} \mathrm{C}$ for $30 \mathrm{~s}$, the specific annealing temperature for each primer pair for $45 \mathrm{~s}$ and $72{ }^{\circ} \mathrm{C}$ during $1 \mathrm{~min}$, with a final phase at $72^{\circ} \mathrm{C}$ for $5 \mathrm{~min}$. The annealing temperatures were $64{ }^{\circ} \mathrm{C}$ for the growth hormone gene, $67{ }^{\circ} \mathrm{C}$ for the $37 L R P / p 40$ gene and $63{ }^{\circ} \mathrm{C}$ for the $M C 1 R$ gene.

The PCR products were separated on an agarose gel (1.25\%) stained with ethidium bromide $\left(0.5 \mu \mathrm{g} \cdot \mathrm{mL}^{-1}\right)$. Then the bands were extracted from the gel and purified with a DNA Gel Extraction Kit (MILLIPORE Corporation) to be sequenced in a 3100 Avant sequencer from Applied Biosystems. The sequences were tested with Blast [1] to check that the sequenced genes corresponded to the chicken genes that we were looking for in our samples of partridges.

BioEdit [10] software was used to align the resulting sequences with CLUSTALW multiple alignment and its posterior analysis and search for SNP. For the alignment, we used the sequences in both directions in each animal to establish a consensus sequence for each one. Then they were compared with the original sequences from the chicken.

Exonic regions of the aligned sequences were then translated into aminoacids with DNALC Bioinformatics-DNALC Nucleotide Analyser [6]. Differences between translations of partridge sequences and chicken sequences were then analysed. 
Table I. GenBank Accesion Number and primer sequences for each locus.

\begin{tabular}{lcccc}
\hline Locus & $\begin{array}{c}\text { GenBank } \\
\text { Accesion } \\
\text { Number }\end{array}$ & $\begin{array}{c}\text { Nature } \\
\text { of the } \\
\text { amplicon (number) }\end{array}$ & $\begin{array}{c}\text { Primer } \\
\mathrm{F}\left(5^{\prime}-3^{\prime}\right)\end{array}$ & $\begin{array}{c}\text { Primer } \\
\mathrm{R}\left(5^{\prime}-3^{\prime}\right)\end{array}$ \\
\hline$G H$ & AB061722 & intron (4) & GCACTGAGGG & ACGAAAATGT \\
& & & ACGTGGTTAT & CAGGACGGAG \\
$37 L R P / p 40$ & $\mathrm{X} 94368$ & intron (5) & GGGCCTGATGT & GCTTTCTCAGC \\
& & & GGTGGATGCTGGC & AGCAGCCTGCTC \\
$M C 1 R$ & D78272 & exon & ATCCCCAAT & CAGCGCATA \\
& & & GAGCTCTTCCT & GAAGATGGTGA \\
\hline
\end{tabular}

Table II. Number of SNP in each locus. Gallus gallus is the reference species for the sequence comparative study. N. studied A. rufa and N. studied A. chukar are the number of animals in each species of Alectoris that were used in this work. N. studied bp is the number of base pairs of each compared gene. N. SNP Alectoris-reference species is the number of SNP that were found between Alectoris species and Gallus gallus. N. SNP A. rufa-A. chukar is the number of different SNP between A. rufa and A. chukar.

\begin{tabular}{|c|c|c|c|c|c|c|}
\hline Locus & $\begin{array}{c}\text { Reference } \\
\text { species }\end{array}$ & $\begin{array}{l}\text { N. studied } \\
\text { A. rufa }\end{array}$ & $\begin{array}{l}\text { N. studied } \\
\text { A. chukar }\end{array}$ & $\begin{array}{c}\text { N. studied } \\
\text { bp }\end{array}$ & $\begin{array}{c}\text { N. SNP } \\
\text { Alectoris-reference } \\
\text { species }\end{array}$ & $\begin{array}{c}\text { N. SNP } \\
\text { A. rufa-A. chukar }\end{array}$ \\
\hline$G H$ (intron) & G. gallus & 30 & 20 & 201 & 17 & 2 \\
\hline $\begin{array}{l}37 L R P / p 40 \\
\text { (intron) }\end{array}$ & G. gallus & 30 & 20 & 314 & 14 & 0 \\
\hline $\begin{array}{l}M C 1 R \\
\text { (exon) }\end{array}$ & G. gallus & 30 & 20 & 336 & 5 & 0 \\
\hline
\end{tabular}

\section{RESULTS}

The results of the total sequences analysed from $G H, 37 L R P / p 40$ and $M C 1 R$ genes are shown in Table II. The number of SNP between Alectoris and Gallus were obtained when a base nucleotide was common to both species of Alectoris and that nucleotide was different in Gallus gallus.

The growth hormone gene was sequenced in 50 partridges. A nucleotide change in 17 positions and 4 indels was observed when comparing the chicken sequence with the consensus sequence from both partridge species (Fig. 2). Between the red-legged partridge and the chukar partridge there were two interspecific SNP at positions 61 and 156 (Fig. 2). There were also differences among A. chukar from different geographic locations. For the growth hormone gene, the compared sequence was an intron.

The $37 L R P / p 40$ gene was sequenced in 50 birds. Fourteen SNP among the chicken and the partridge and 18 indels were located (Fig. 2). When comparing A. rufa with $A$. chukar, we did not obtain any interspecific SNP. There were some differences depending on the origin of the partridges. For this gene in the exonic region (1 to 89 and 300 to 311 from Fig. 2) there is only one SNP that corresponds to $\mathrm{G} \rightarrow \mathrm{A}$ in position 38 (Fig. 2), but it had the same translation (glutamin).

Finally, the $M C 1 R$ gene was sequenced in 50 animals. Eight SNP were located when comparing partridge sequences with 
Alignment of $G H$ sequences

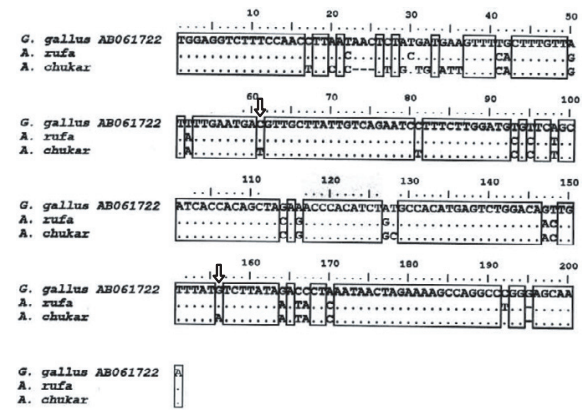

Alignment of $L R P / p 40$

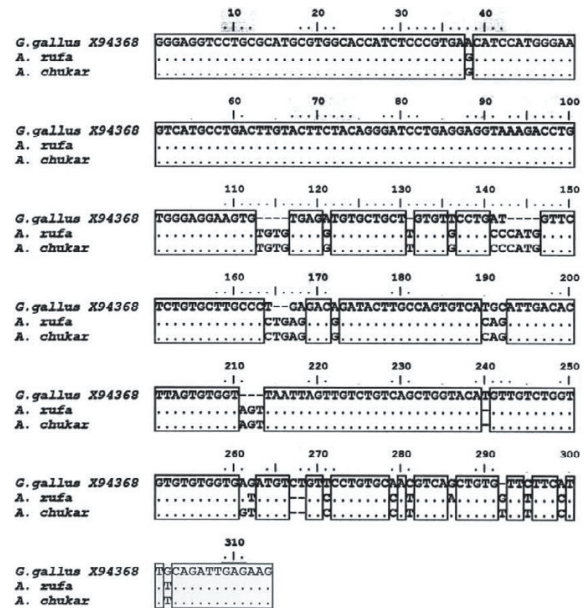

Alignment of $M C 1 R$ sequences
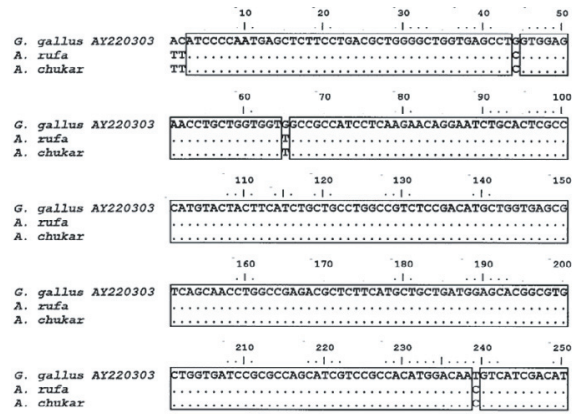

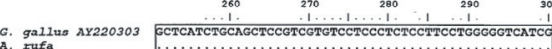

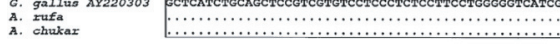

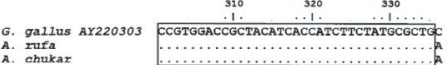

Figure 2. Alignment of DNA sequences from chickens and partridges ( $\mathrm{N}$ means errors of sequencing). The arrows indicate the interspecific SNP.

those of the chicken (Fig. 2). Three to five changes differentiate the partridge sequence from the various chicken sequences available in GenBank (3 SNP in positions 44, 65 and 239 with Gallus $M C 1 R$ sequences AY220303, AB201630, AB201629, AB201628, 5 SNP in positions 44, 65, 165, 239 and 267 with AY220304 and 5 SNP in positions 44, 65, 103, 165 and 239 with AY220305, NM_001031462, AB201631 and D78272). These changes affect the translation between Gallus and the partridge as shown in Figure 3: thr103met, lys165glu and ile267val.
The nucleotide sequences data reported in this paper have been submitted to the GenBank nucleotide sequence database and have been assigned the Accession Numbers: AY606819, AY606820, AY606821, AY606822, AY762966 and AY762967.

\section{DISCUSSION}

The gene sequences of the growth hormone, $37 L R P / p 40$ and $M C 1 R$ of the chicken were quite different from the partridge, with 57 different positions 


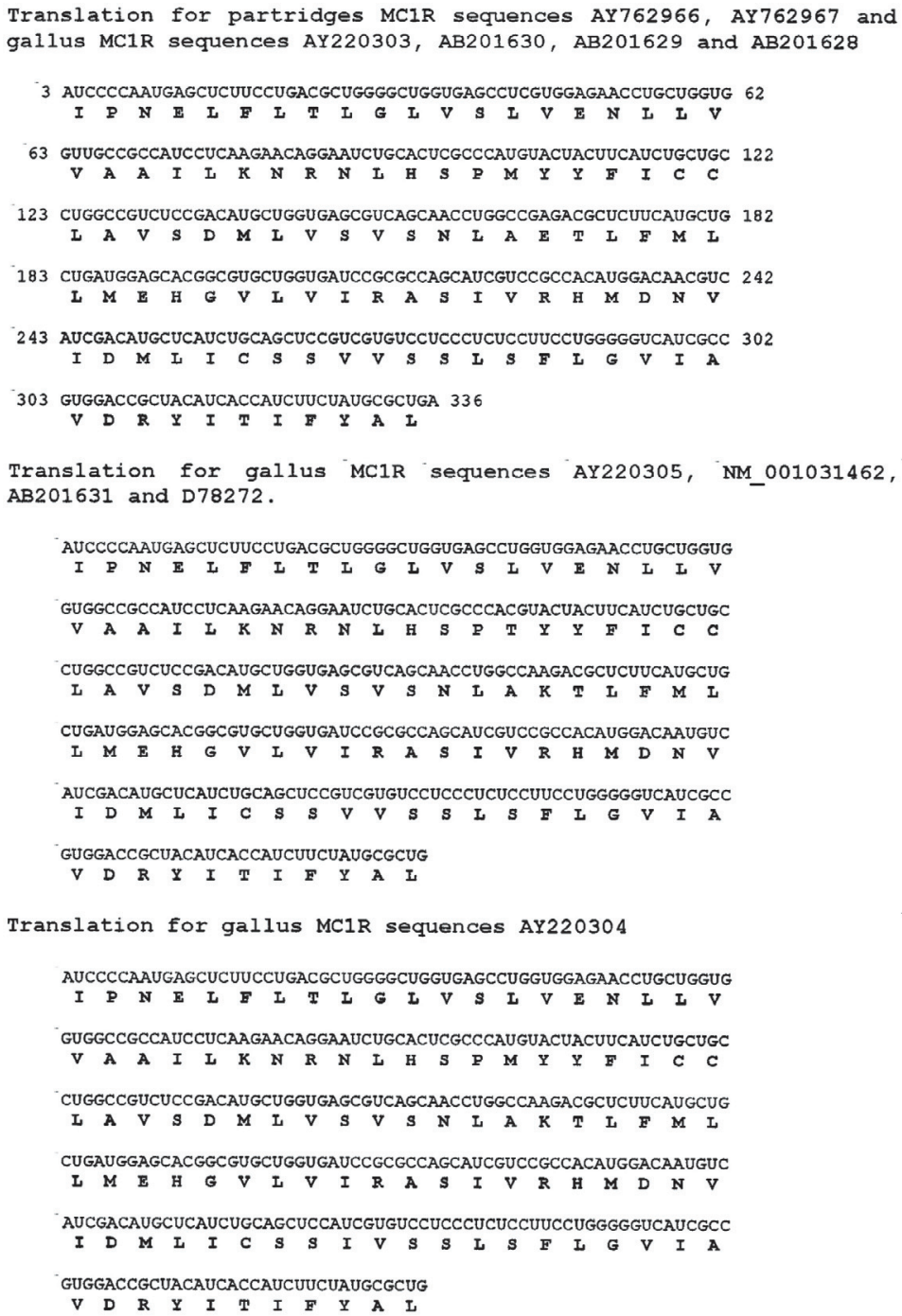

Figure 3. Different translations of $M C 1 R$ sequences in chickens and partridges.

(including indels), out of $851 \mathrm{bp}$ studied and it could be due to the nature of the amplicons (mainly introns). The most abundant SNP were transitions $(\mathrm{T} \rightarrow \mathrm{C}, \mathrm{A} \rightarrow$ $\mathrm{G}, \mathrm{C} \rightarrow \mathrm{T}$ and $\mathrm{G} \rightarrow \mathrm{A}$ from most to least frequent) which made up $61.54 \%$ of all the SNP between these species.

Although many SNP have been found between the chicken and partridge when comparing translations of exonic regions (part of $37 L R P / p 40$ and $M C 1 R$ genes), there are no differences and proteins would be the same. This occurs when the comparison of the partridge $M C 1 R$ gene is made with the chicken $M C 1 R$-e+ allele that is the most similar to it. Most SNP (30 out of 39) are in intronic regions as we expected. 
Regarding the red-legged and chukar partridge, there were two interspecific SNP out of 851 base pairs sequenced (total rate of $1 \mathrm{SNP} / 425 \mathrm{pb}$ ), which can be used to differentiate between these species. These variations were transitions. Although SNP between chickens and partridges have been found in the three genes, only SNP in the $G H$ gene can be used to distinguish between red-legged and chukar partridges. The genetic variability that we found in the Alectoris rufa population or in the A. chukar population is individual variation and it can not be considered for the identification of real SNP between both Alectoris species or between Alectoris and Gallus.

The results provide some information about the sequencing of the chukar partridge and red-legged partridge and help to create a point of reference to identify individual partridges as a species via their DNA using interspecific SNP in order to avoid repopulating with chukar individuals or wrong labelling of partridge products. In order to amplify this study, SNP genotyping by real time PCR could be developed for the practical use of the SNP detected.

This could be an important way to help red-legged partridge conservation because according to laws it is compulsory to repopulate with pure red-legged partridges and it is an ecologically important species as well.

In the same way, the techniques described here can be used efficiently in evolutionary bird studies.

\section{ACKNOWLEDGEMENTS}

This work has been supported by an INIA project with reference number: RZ2004-0001100-00 and a grant to CBG from the Spanish Ministry of Education, Culture and Sports.

\section{REFERENCES}

[1] Altschul S.F., Madden T.L., Schäffer A.A., Zhang J., Zhang Z., Miller W., Lipman D.J.,
Gapped BLAST and PSI-BLAST: a new generation of protein database search programs, Nucl. Acid. R. 25 (1997) 3389-3402.

[2] Armstrong M.H., Braun E.L., Kimball R.T., Phylogenetic Utility of Avian Ovomucoid Intron G: A Comparison of Nuclear and Mitochondrial Phylogenies in Galliformes, The Auk 118 (2001) 799-804.

[3] Arruga M.V., Tejedor M.T., Villaroel M.R., Heriz A., Ferreira E., Abenia F.J., Genetic studies in Alectoris rufa and Alectoris graeca in Spain, 12th European Colloquium on Cytogenetics of Domestic Animals, Cytogenet. Cell Genet. 74 (1996) 228.

[4] Arruga M.V., Tejedor M.T., Saz J., Monteagudo L.V., Villarroel M., Avances en la determinación de la pureza genética de la perdiz roja. II Jornadas técnicas Progalter, Expoaviga 98 (1998) 9-14.

[5] Clausse N., Jackers P., Jares P., Joris B., Sobel M.E., Castronovo V., Identification of the active gene coding for the metastasisassociated $37 \mathrm{LRP} / \mathrm{p} 40$ multifunctional protein, DNA Cell Biol. 15 (1996) 1009-1023.

[6] DNALC, Bioinformatics-DNALC Nucleotide Analyzer [Online] Available: http://www.dnalc.org / bioinformatics / 2003/ 2003_dnalc_nucleotide_analyzer.htm [June 2004].

[7] Fotouhi N., Karatzas C.N., Kuhnlein U., Zadworny D., Identification of growth hormone DNA polymorphisms which respond to divergent selection for abdominal fat content in chickens, Theor. Appl. Genet. 85 (1993) 931-936.

[8] García C.B., Arruga M.V., Advances in DNA analysis by RAPD methodology in a little studied genetically avian species (Alectoris rufa, L.), Poult. Avian Biol. Rev. (2006) in press.

[9] GenBank nucleotide sequence database [Online] Available: http://www.ncbi.nlm. nih.gov / entrez / query.fcgi?db = Nucleotide [November 2004].

[10] Hall T.A., BioEdit: a user-friendly biological sequence alignment editor and analysis program for Windows 95/98/NT, Nucl. Acids Symp. Ser. 41 (1999) 95-98.

[11] Kasai F., Garcia C.B., Arruga M.V., Ferguson-Smith M., Chromosome homology between chicken (Gallus gallus domesticus) and the red-legged partridge (Alectoris rufa); evidence of the occurrence of a neocentromere during evolution, Cytogenet. Genome Res. 102 (2003) 326-330. 
[12] Kerje S., Lind J., Schütz K., Jensen P., Andersson L., Melanocortin 1-receptor $(M C 1 R)$ mutations are associated with plumage colour in chicken, Anim. Genet. 34 (2001) 241-248.

[13] Kuhnlein U., Ni L., Weigend S., Gavora J.S., Fairfull W., Zadworny D., DNA polymorphism in the chicken growth hormone gene: response to selection for disease resistance and association with egg production, Anim. Genet. 28 (1997) 116-123.

[14] Landegren U., Nilsson M., Kwok P.-Y., Reading bits of genetic information: methods for single-nucleotide polymorphism analysis, Genome Res. 8 (1998) 769-776.

[15] Leung F.C., Zhang X.-Q., Ip S.C.-Y., Chicken growth hormone polymorphism in native Chinese chicken, Poultry Sci. 78 (Suppl. 1) (1999) 61.

[16] Ling M.K., Lagerström M.C., Frediksson R., Okimoto R., Mundy N.I., Takeuchi S., Schiöth H.B., Association of feather colour with consecutively active melanocortin 1 receptors in chicken, Eur. J. Biochem. 270 (2003) 1441-1449.

[17] Negro J.J., Torres M.J., Godoy J.A., RAPD analysis for detection and eradication of hybrid partridges (Alectoris rufa $\times$ Alectoris graeca) in Spain, Biol. Conserv. 98 (2001) $19-24$.

[18] Primmer C.R., Borge T., Lindell J., Saetre G.P., Single-nucleotide polymorphism characterization in species with limited available sequence information: high nucleotide diversity revealed in the avian genome, Mol. Ecol. 11 (2002) 603-612.
[19] Randi E., Lucchini V., Organization and evolution of the mitochondrial DNA control region in the avian genus Alectoris, J. Mol. Evol. 47 (1998) 449-462.

[20] Rozen S., Skaletsky H.J., Subject: Primer 3, 1998, [Online] Available: http://www. genome.wi.mit.edu/cgi-bin/primer/primer3.cgi/ primer3_www.cgi [December 2003]

[21] Saz J., Arruga M.V., Tejedor M.T., Villarroel M., Savva D., Genetic differentiation in Alectoris rufa and A. graeca from Spain, Hungarian J. Anim. Prod. 48 (1998) 86-89.

[22] Shi L., Drummond P., De Kloet S., PimentelSmith G.E., Smith E.J., Comparative DNA sequence analysis of genetic variation in the African grey parrot, Psittacus erythacus, Genetica 110 (2001) 227-230.

[23] Smith E., Shi L., Drummond P., Rodriguez L., Hamilton R., Powell E., Nahashon S., Ramlal S., Smith G., Foster J., Development and characterization of expressed sequence tags for the turkey (Meleagris gallopavo) genome and comparative sequence analysis with other birds, Anim. Genet. 31 (2000) 6267.

[24] Tanaka M., Hosokawa Y., Watahiki M., Nakashima K., Structure of the chicken growth hormone-encoding gene and its promoter region, Gene 112 (1992) 235-239.

[25] Tucker G.M., Heath M.F., Birds in Europe: Their conservation Status, Birdlife Conservation Series No. 3, Birdlife International, Cambridge, UK, 1994.

[26] Yung W., Chan C., Leung F., PCR Analysis of chicken growth hormone gene polymorphism, Poultry Sci. 77 (Suppl. 1) (1998) 6.

To access this journal online: www.edpsciences.org 